\title{
O strategiach grzecznościowych polskich i niemieckich studentów na przykładzie reakcji na komplementy
}

\section{Politeness strategies in compliment responses of Polish and German students}

\author{
Violetta Frankowska \\ Instytut Filologii Germańskiej \\ Uniwersytet im. Adama Mickiewicza \\ al. Niepodległości 4, 61-874 Poznán
}

\begin{abstract}
This article presents the complimenting behaviour of German and Polish students: strategies they use when respoding to compliments. The speech act was also analysed as regards the concept of face and positive and negative politeness. A corpus of 345 German and Polish compliment responses was examinated. The results show the existence of cross-cultural differences as well as similarities between the two groups of students. The article presents parts of author's Master's Thesis.
\end{abstract}

\section{Wstęp}

Komplementy, choć zjawisko tak codzienne i każdemu z nas dobrze znane, stanowią obiekt intensywnych badań lingwistycznych dopiero od około 30 lat. Co prawda zalicza się je do aktów dodatniego wartościowania, zorientowanych przede wszystkim na sprawieniu radości partnerowi komunikacyjnemu, ale okazuje się 
jednak, że reakcja na nie może być dość problematyczna i krępujaca dla osoby komplementowanej, a dla nadawcy komplementu nieoczekiwana i niezamierzona. To, w jaki sposób dobieramy i odbieramy komplementy w określonych sytuacjach zależy nie tylko od czynników indywidualnych i kontekstu sytuacyjnego, lecz jest również uwarunkowane kulturowo. I to wlaśnie $\mathrm{m}$. in. kulturowa różnorodność i oryginalność komplementów oraz reakcji na nie czyni je tak interesujacymi (zwłaszcza dla badań kontrastywnych) aktami mowy, w których znajduje odbicie mentalność i system wartości kultur oraz wylania się obraz charakterystycznej dla nich grzeczności.

Celem niniejszego artykułu jest przedstawienie różnic i podobieństw występujących w reakcjach na komplementy u polskich i niemieckich studentów. Druga część stanowi krótkie wprowadzenie teoretyczne, w następnej części opisano korpus. Trzecia i czwarta część zawiera wyniki analizy, które stanowią fragment pracy magisterskiej autorki. Starano się odpowiedzieć $m$. in. na pytania:

- jaki wplyw na reakcje na komplement „Dzisiaj wyglądasz pięknie" ma zawarty w nim okolicznik czasu dzisiaj?,

- jak ksztaltują się ogólne preferencje Polaków i Niemców w wyborze strategii reagowania na komplement?

- jaki obraz grzeczności Niemców i Polaków wyłania się z zebranego materialu?

\section{Komplement a grzeczność}

Komplementy to strategie grzecznościowe, z którymi spotykamy się na co dzień, zarówno jako ich nadawcy, jak i odbiorcy. Cechuja się multifunkcjonalnością - pelnią $m$. in. funkcję ekspresywna, społeczną, informacyjną i wartościująca, a ich brak w pewnych sytuacjach uchodzi wręcz za niegrzeczność. Dziś powszechnie znana jest teoria grzeczności Brown i Levinsona z roku 1987, która bazuje na koncepcie twarzy Goffmana. Komplement pomaga interaktantom dbać o "twarze" we wzajemnej komunikacji, czasami jednak może im również zagrozić. 


\subsection{Nasze "twarze"}

W oparciu na stworzonym przez Goffmana pojęciu "face" ("twarz"), rozumianej jako image każdego czlowieka, jego tożsamość, kreowany obraz w spoleczeństwie, Brown i Levinson wyróżniają dwa rodzaje twarzy: twarz pozytywnq oraz twarz negatywnq. Twarz pozytywna wyraża się w chęci do bycia akceptowanym, rozumianym oraz podziwianym (por. Schulze 1985: 78), natomiast twarz negatywna to "nasza potrzeba do 'wlasnego terytorium', to prawo do samookreślenia i obrony tego terytorium, a także wolności w jego obrębie" (Mikolajczyk 2008: 187), a więc nasze dążenie do zachowania dystansu, niezależności, autonomii, wolności dzialania czy respektu. Można zatem dojść do wniosku, że potrzeby obydwu twarzy stanowią dwa dość różne bieguny, których jednoczesne zaspokojenie zdaje się być niemożliwe.

\subsection{Grzeczność pozytywna i negatywna}

Brown i Levinson, opierając się na dwóch rodzajach twarzy, wyróżniają tzw. grzeczność pozytywnq (positive politeness), czyli dzialania zmierzające ku zaspokojeniu życzeń twarzy pozytywnej, mówienie tego, co mile, nieograniczanie wolności i swobody dzialania partnera, oraz grzeczność negatywnq (negative politeness), która oslabia lub pozwala uniknąć aktów bezpośrednich takich jak np. rozkaz i tym samym niwelować zagrożenie twarzy. Jej zadanie polega więc na zminimalizowaniu niegrzeczności niegrzecznych aktów illokucyjnych (por. Zborowski 2005: 29), na dbaniu o twarz negatywna, a więc dzięki niej uzyskuje się wolność - „freedom to act without being impeded by others" (Lorenzodus 2001: 108).

\subsection{Dylemat osoby komplementowanej}

W życiu codziennym pojawiają się czasem sytuacje, w których trudno dokonać odpowiedniego wyboru związanego z werbalną 
i/lub niewerbalną reakcją na komplement, która bylaby zgodna $z$ uczuciami i jednocześnie zasadami grzeczności obowiązujacymi w naszym otoczeniu. Co ciekawe, dotyczy to również komplementów, których jedną $z$ najważniejszych funkcji jest przecież sprawienie adresatowi radości. Bywa jednak i tak, że ten pozornie lubiany i pożądany akt mowy wywoluje u odbiorcy niepewność, nieśmialość, skrępowanie, dylemat związany z odpowiedzią na niego czy w skrajnych przypadkach złość, a nawet może zostać odebrany jako obelga.

Na podstawie wyników badań dotyczących reakcji na komplementy stworzono różne systemy ich klasyfikacji, mające jednak wspólne cechy. Nicolaysen (2007: 101), powolując się na klasyfikację Pomerantz (1978) oraz Herberta (1986), podaje trzy możliwe typy odpowiedzi na ten akt mowy:

1. akceptacja - pozytywna twarz osoby komplementujacej zostaje zachowana, istnieje ryzyko utraty twarzy osoby komplementowane $j^{1}$

2. odrzucenie - potencjalny akt zagrażajacy twarzy osoby komplementujacej $^{2}$

3. unikanie chwalenia się - strategia lącząca element przyjęcia komplementu przy jednoczesnym częściowym odrzuceniu, co może również zagrozić twarzy osoby komplementującej

I tak próbując zachować wlasną twarz, stanowimy potencjalne zagrożenie twarzy naszego partnera rozmowy, gdyż ,czlowiek może osiagnąć swój zamierzony cel częściowo tylko poprzez naruszenie praw do wlasnego terytorium innych interaktantów" (ZBOROwSKI 2005: 33, thum. V.F.), próbując zachować twarz naszego rozmówcy, możemy stracić przy tym wlasna. Również on, zachowując swoja twarz, zagraża naszej, a próbując sprostać potrzebom naszej twarzy, może zaatakować swoją.

$1 \quad$ Akceptacja może się wiazzać z odebraniem osoby komplementowanej przez nadawcę komplementu jako osoby nieskromnej i przesadnie pewnej swojej wartości.

2 Należy tu jednak zaznaczyć, że odrzucenie komplementu w niektórych kulturach - przede wszystkim azjatyckich - jest najgrzeczniejszą z możliwych reakcji na ten akt mowy, a akceptacja stanowi przejaw braku skromności. 
Tak więc można dojść do wniosku, że cokolwiek by się odpowiedziało, to i tak zagrożenie twarzy jest prawie niemożliwe. $Z$ pomoca przychodzi jednak partnerom interakcji grzeczność, postrzegana jako „zbiór strategii zachowania stosowanych w celu zachowania twarzy mówcy i odbiorcy" (Mikolajczyk 2008: 187), która w dużej mierze pomaga unikać problematycznych sytuacji. ${ }^{3}$

\section{Metodologia}

Korpus niniejszej analizy stanowią ankiety (w zalączniku polska wersja) przeprowadzone pośród 58 niemieckich studentów (30 studentek, 28 studentów) oraz 57 polskich studentów (29 studentek oraz 28 studentów). Ankietowani to studenci Uniwersytetu im. Adama Mickiewicza w Poznaniu, Uniwersytetu Ekonomicznego w Poznaniu oraz studenci Uniwersytetu Bielefeld w wieku od 19 do 28 lat, studiujący kierunki nielingwistyczne. Ich zadanie polegało na zapisaniu swoich werbalnych reakcji na komplementy występujace $w$ trzech przedstawionych sytuacjach, tak więc lączna suma wszystkich zebranych odpowiedzi na komplementy wyniosła 345 . Należy tutaj zaznaczyć, że niektórzy studiujacy nie podali dokladnej reakcji słownej, lecz dokonali opisu swoich emocji i zachowań, co w niektórych przypadkach utrudnilo klasyfikację ich odpowiedzi. Ostatecznie liczba reakcji werbalnych i niewerbalnych przedstawia się następująco:

- 174 reakcje Niemców $=123$ werbalne +51 niewerbalne

- 171 reakcji Polaków $=119$ werbalne +52 niewerbalne

3 Nie zawsze jednak zasady grzeczności idą w parze z subiektywnymi odczuciami i to wlaśnie emocje biora czasem górę. Dzieje się tak zazwyczaj wtedy, gdy odbiorca komplementu nie wierzy w szczerość osoby komplementującej i nie zależy mu na dalszych pozytywnych relacjach z nią. Dowodem sa te oto przyklady reakcji polskich studentów na ten sam komplement ,W tej nowej fryzurze wyglądasz świetnie", wypowiedziany przez nielubianą osobę:

A. „grzeczne” odpowiedzi: Sie wie $\square$ Cieszę się oczywiście lub Zmartwię się, że chyba źle wygladam, ale i tak uśmiechnę się i grzecznie podziękuję.

B. ,niegrzeczne" odpowiedzi: Akurat, nie udawaj lepiej! Nie lubię szyderczości czy Dobra dobra, weź mi tutaj nie ściemniaj i tak masz mnie w dupie. 
W niniejszym artykule opisano przede wszystkim wybrane wyniki analizy w odniesieniu do reakcji werbalnych.

\section{Komplement Dzisiaj wyglqdasz, pięknie!}

Jedna $\mathrm{z}$ sytuacji przedstawionych $\mathrm{w}$ ankiecie zawierala komplement Dzisiaj wyglqdasz pięknie! Jej celem bylo określenie wplywu okolicznika czasu $d z i s i a j$ na reakcje ankietowanych oraz wykrycie ewentualnych różnic i podobieństw w ogólnych preferencjach niemieckich i polskich studentów w wyborze strategii zachowań po uslyszeniu tego komplementu.

\subsection{Wpływ okolicznika czasu na odpowiedzi respondentów}

Wśród wszystkich 115 werbalnych i niewerbalnych reakcji Niemców i Polaków na komplement Dzisiaj wyglądasz pięknie! znaleziono w sumie tylko 7 przykładów odpowiedzi (2 niemieckie i 5 polskich), w których dzisiaj ma wplyw na odbiór tego aktu mowy. Kolejne dwie części tego artykulu mają na celu omówienie tych kilku przypadków.

\subsubsection{Reakcje niezwerbalizowane}

W trzech z siedmiu odpowiedziach na komplement z widocznym wplywem okolicznika czasu dzisiaj studenci nie podali bezpośredniej reakcji słownej, a jedynie opisali swoje uczucia. Dwa przyklady pochodza z polskiego korpusu i zostaly sformulowane przez studentkę i studenta następująco:

Czuję się niezręcznie, bo nie jestem przyzwyczajona do takich reakcji i zwracania na siebie uwagi. Jest mi jednak bardzo milo, choć gdzieś na dnie czuję ukłucie: „A więc na co dzień wyglądam szaro i ponuro".

Przechodzi przeze mnie niepokój, że w takim razie wcześniej wyglądałem bardzo źle. 
Można zauważyć, że w obydwu przypadkach okolicznik czasu wywoluje negatywne uczucia u odbiorców komplementu i powoduje niepewność dotyczącą wygladu w innych dniach. U studentki pojawia się dodatkowo problem $\mathrm{z}$ reagowaniem na taki akt mowy, spowodowany prawdopodobnie malą liczbą otrzymywanych komplementów na co dzień. Niemniej jednak ważna funkcja tego aktu mowy zostala spełniona, ponieważ osobie nim obdarowanej jest miło.

W niemieckim korpusie znaleziono jedną reakcję studentki, która brzmi:

Ich freue mich sehr und überlege, ob ich in Zukunft nicht öfters dementsprechende Kleidung tragen sollte. Allerdings kommt mir der Gedanke, ob ich denn sonst nicht schön aussehe.

Również u niej pojawiaja się watpliwości dotyczące wygląu przy równoczesnej radości z komplementu. Poza tym ten akt mowy wywoluje $\mathrm{u}$ odbiorcy myśl o ewentualnych zmianach wizerunku w przyszlości.

Ponieważ ankietowani nie podali tutaj dokładnej reakcji slownej, uslyszanej przez osobę komplementującą nie można stwierdzić, jakie strategie zostały użyte bezpośrednio i czy zaistnial ewentualny atak na ,twarz" partnerów interakcji czy też jej utrata.

\subsubsection{Reakcje werbalne}

O wiele ciekawsze są reakcje slowne, wypowiedziane wprost do osoby komplementującej. Dwa poniższe przykłady odpowiedzi studentek z Polski i z Niemiec

Wundere mich, vielleicht sehe ich sonst nicht gut aus! Denke darüber nach, ob evtl. meine Kleidung sonst nicht so gut aussieht. „Danke.“

„Acha (sic!), czyli do tej pory wyglądałam okropnie”, taka myśl przychodzi mi do glowy. Dziękuję mimo wszystko, ale w glębi duszy jednak mam podejrzenia, że dotychczas 
niezbyt dobrze wyglądalam... Jednocześnie powinien być to sygnał, że może jednak powinnam coś w sobie zmienić.

są charakterystycznym przykładem działania strategicznego, którego celem jest w tym przypadku nieokazywanie negatywnych uczuć związanych z otrzymanym komplementem po to, by nie stanowić potencjalnego ataku na twarz osoby komplementującej. Obydwie studentki dziękują za komplement i tym samym przyjmuja go. Fakt ten pozwala przypuszczać, że akt podziękowania stanowi w obydwu kulturach oczekiwana i zarazem grzeczna odpowiedź w takiej sytuacji. Nie wyrażając slownie swoich watpliwości dbają o twarz partnera interakcji, by móc w dalszym ciagu utrzymywać pozytywną relację z nim. Podobnych przykladów ,grzecznych odpowiedzi" nie znaleziono u studentów. Wśród Polaków zarysowala się calkiem inna tendencja, o czym świadczą te oto przykłady:

Najprawdopodobniej zapytalbym: „Co to znaczy >dzisiaj $<$ ?” z nutką dowcipu i ironii.

Pytam się go, czy to oznacza, że zazwyczaj nie wyglądam ladnie.

W obydwu reakcjach można stwierdzić potencjalne zagrożenie twarzy osoby komplementujacej-komplement nie zostaje przyjęty. Osoby komplementowane bezpośrednio wyrażają swoje emocje i nie stosuja przy tym pomniejszenia aktu zagrażającego twarzy (może jedynie w pierwszym przypadku nutka dowcipu w jakiś sposób zlagodziła atak). Warto podkreślić, że pytanie zwrotne jako odpowiedź na komplement jest spowodowane okolicznikiem dzisiaj. Nadawca komplementu znajduje się w dość trudnej sytuacji, w której musi zareagować na reakcję odbiorcy. Inna interpretacja pozwala przypuszczać, że zadane pytanie jest rodzajem fishing for compliments, które ma na celu uzyskanie od osoby komplementującej dodatkowego potwierdzenia i wzmocnienia czy też powtórzenia komplementu. Rzuca się w oczy fakt, że okolicznik czasu dzisiaj nie miał żadnego wplywu na odbiór komplementu przez niemieckich studentów. 
Przytoczone wyżej przyklady dowodza, że dzisiaj może wplynać negatywnie na odbiór komplementu i z jednej strony zmuszać jego odbiorcę do stosowania strategii grzecznościowych w formie podziękowania, które ma na celu uchronienie nadawcy przed utratą twarzy oraz nienarażanie komunikacji na zachwianie, jak bylo w przypadku werbalnych reakcji studentek polskich i niemieckich, a z drugiej strony wywołać niemile uczucia u odbiorcy, które ten wyrazi bezpośrednio - przyklady polskich studentów. Być może taka reakcja wśród płci męskiej nie stanowi tak mocnego zagrożenia twarzy, jak mogłoby to mieć miejsce u studentek.

Biorąc pod uwagę fakt, że na 115 reakcji w 7 zaobserwowano wplyw okolicznika na reakcję (wyrażony w sposób werbalny lub też ukryty przed nadawca), co stanowi niespelna $6,1 \%$ wszystkich odpowiedzi korpusu polskiego i niemieckiego na tę sytuację, należy stwierdzić, że wplyw ten, choć negatywny, dotyczy malej liczby odpowiedzi. Dla olbrzymiej większości respondentów obecność dzisiaj w akcie pozytywnego wartościowania nie przeklada się na charakter reakcji.

\subsection{Ogólne preferencje polskich i niemieckich studentów w reagowaniu na komplement "Dzisiaj wyglądasz pięknie!"}

Po sklasyfikowaniu wszystkich reakcji werbalnych niemieckich i polskich studentów na komplement Dzisiaj wygladasz pięknie w kategoriach akceptacji, odrzucenia komplementu oraz kategorii pośredniej, lączącej w sobie elementy akceptacji oraz próby częściowego odrzucenia tego aktu mowy bądź odwzajemnienia komplementu lub pomniejszenia obiektu komplementowanego, czyli unikania chwalenia się, uzyskano następujące wyniki: 


\begin{tabular}{l|c|c|c|c}
\multirow{2}{*}{ Typ odpowiedzi } & \multicolumn{2}{c|}{$\begin{array}{c}\text { niemieccy } \\
\text { respondenci }\end{array}$} & \multicolumn{2}{c}{$\begin{array}{c}\text { polscy } \\
\text { respondenci }\end{array}$} \\
\cline { 2 - 5 } & liczba & $\%$ & liczba & $\%$ \\
\hline I Akceptacja & 29 & 74,4 & 21 & 60 \\
\hline II Odrzucenie & 1 & 2,6 & 3 & 8,6 \\
\hline $\begin{array}{l}\text { III Uniknięcie } \\
\text { chwalenia się }\end{array}$ & 9 & 23 & 11 & 31,4 \\
\hline suma & 39 & 100 & 35 & 100
\end{tabular}

Tabela 1. Porównanie strategii reagowania na komplement „Dzisiaj wyglądasz pięknie" przez Niemców i Polaków

Widać wyraźnie, że akceptacja stanowi co prawda w obydwu grupach najważniejszą strategię reagowania na komplement, ale w przypadku Niemców ta liczba jest o 14,4\% wyższa. Drugim co do częstości stosowania typem odpowiedzi w obydwu grupach respondentów jest próba przywrócenia równowagi w rozmowie poprzez dowartościowanie osoby komplementujacej badź umniejszenie obiektu komplementu czy też transfer, służace unikaniu chwalenia się, ale i w tym przypadku widoczna jest różnica w frekwencji jej występowania - Polacy sięgaja po takie rozwiązanie o $8,4 \%$ częściej.

W obydwu grupach ankietowanych odrzucenie komplementu nie należy do ulubionych strategii. Tu widoczna jest olbrzymia różnica między kulturą niemiecką czy polska, a np. kultura chińska, w której to wlaśnie odrzucenie komplementu stanowi najważniejsza i najczęściej stosowaną strategię grzecznościowa, która jest manifestacją skromności (patrz Chen 1993). U Polaków za odrzucenie komplementu odpowiedzialny jest glównie okolicznik czasu dzisiaj, poza tym wystapila również jedna reakcja Eee ... Wydaje Ci się, która również może stanowić potencjalne zagrożenie twarzy nadawcy komplementu. 


\subsection{Porównanie odpowiedzi występujących w strategii unikania chwalenia się}

Poniższa tabela przedstawia zachowania polskich i niemieckich studentów, przypisane kategorii unikania chwalenia samego siebie i pozwalające przywrócić równowagę w rozmowie. Liczby w nawiasie oznaczaja częstość pojawienia się danej kombinacji elementów w reakcjach:

\begin{tabular}{|c|c|c|}
\hline & Niemcy & Polacy \\
\hline$\frac{\bar{z}}{\overline{0}}$ & $\begin{array}{l}\text { „dziękuję" + zmiana tematu } \\
\text { (1) } \\
\text { "dziękuje" + komentarz + ? } \\
(1) \\
\text { transfer + komentarz (1) }\end{array}$ & $\begin{array}{l}\text { „dziękuje” + komentarz (3) } \\
\text { komentarz (1) }\end{array}$ \\
\hline$\frac{\bar{y}}{\overline{0}}$ & $\begin{array}{l}\text { „dziękuje" }+ \text { komplement } \\
\text { zwrotny (4) } \\
\text { komplement zwrotny (2) }\end{array}$ & $\begin{array}{l}\text { "dziękuje" + komplement } \\
\text { zwrotny (1) } \\
\text { „dziękuje" + komentarz (2) } \\
\text { "dziękuje" + zgoda (1) } \\
\text { "dziękuje" + ? (1) } \\
\text { "komentarz" + ? (1) } \\
\text { komentarz (1) }\end{array}$ \\
\hline
\end{tabular}

Szczególnie rzuca się w oczy to, że we wszystkich reakcjach niemieckich studentów przypisanych strategii unikania chwalenia się pojawia się komplement zwrotny (samodzielnie lub w kombinacji $\mathrm{z}$ aktem podziękowania). Wśród polskich studentów znaleziono tylko jeden komplement zwrotny, $\mathrm{a}$ - co ciekawe - $\mathrm{u}$ studentek ani jednego. Polscy respondenci preferują bardziej akt podziękowania, który stanowi u nich glówny element odpowiedzi, polączony ze zgodą komentarzem czy pytaniem. Podobna sytuacja zarysowuje się wśród żeńskiej grupy, która jednak nie stosuje tak bogatego wachlarza kombinacji jak grupa studentów i ogranicza się do aktu podziękowania i komentarzy. Niemieckie studentki również dziękują i komentuja obiekt komplementu, ale poza tym zmieniają temat bądź stosują transfer, czego nie można bylo stwierdzić w przypadku pozostalych grup. 


\section{Frekwencja występowania poszczególnych elementów w reakcjach na komplementy}

Wśród wszystkich 242 werbalnych odpowiedzi studentów znaleziono następujące elementy, które pojawialy się pojedynczo lub tworzyly wspólne kombinacje:

2 akt podziękowania,

3 komentarz,

4 zgodzenie się z komplementem,

5 komplement zwrotny,

6 pytanie (oznaczone w tabelce jako?),

7 zmiana tematu,

8 transfer.

Po zliczeniu ich stworzono tabelę obrazującą różnice we frekwencji ich występowania u polskich i niemieckich studentów:

\begin{tabular}{l|c|c|c|c}
\multirow{2}{*}{$\begin{array}{c}\text { Elementy } \\
\text { kombinacji }\end{array}$} & \multicolumn{2}{c|}{$\begin{array}{c}\text { niemieccy } \\
\text { respondenci }\end{array}$} & \multicolumn{2}{c}{$\begin{array}{c}\text { polscy } \\
\text { respondenci }\end{array}$} \\
\cline { 2 - 5 } & liczba & $\%$ & liczba & $\%$ \\
\hline podziękowanie & 107 & 87 & 101 & 84,9 \\
\hline komentarz & 35 & 28,5 & 35 & 29,4 \\
\hline zgodzenie sie & 17 & 13,8 & 10 & 8,4 \\
\hline komplement zwrotny & 17 & 13,8 & $\mathbf{8}$ & 6,7 \\
\hline ? & 6 & 4,9 & $\mathbf{8}$ & 6,7 \\
\hline zmiana tematu & 4 & 3,3 & 0 & 0 \\
\hline transfer & 2 & 1,6 & 1 & 0,8
\end{tabular}

Tabela 2. Frekwencja występowania poszczególnych elementów kombinacji w werbalnych reakcjach na komplementy polskich i niemieckich studentów 
Widać wyraźnie, jak wielką rolę w odpowiedziach na komplementy odgrywa w obydwu kulturach akt podziękowania. Wśród 123 werbalnych reakcji Niemców podziękowanie pojawia się 107 razy, co stanowi $87 \%$ wszystkich werbalnych odpowiedzi, a więc zdecydowaną większość. Dla porównania, w polskich reakcjach znaleziono 101 podziękowań $(84,9 \%)$. Ten akt mowy występował równeż samodzielnie:

Uśmiecham się szeroko. Mówię dziękuję. Jestem zadowolona.

jak i w kombinacji z innymi elementami, na przyklad ze zgodą czy też zgodą i komplementem zwrotnym:

Z zadowoleniem stwierdzam, że też tak sądzę i dziękuję $\mathrm{z}$ uśmiechem.

Vielen Dank, finde ich auch sehr toll. Du siehst heute aber auch sehr hübsch aus.

Z powyższych przykładów wynika, że podziękowanie pojawia się wtedy, gdy komplement sprawia odbiorcy radość (uśmiecham się szeroko [...] Jestem zadowolona, z zadowoleniem stwierdzam itp.). Bywa i tak, że osoba komplementowana watpi w szczerość mówiącego, nie jest pewna jego dobrej intencji, czy też podejrzewa manipulację. Mimo to nie daje osobie komplementujacej poznać po sobie tych negatywnych emocji i mimo wszystko dziękuje za komplement, a robi to z grzeczności, przykladowo:

Dziękuję (bo nie wypada nie podziękować), ale rozmowy nie kontynuuję, oddalam się, itp.

Dziękuję z uprzejmości, ale nie przywiązuję do tego większej wagi, gdyż jest to tylko koleżanka, a nie moja dziewczyna.

Dziękuję jej, chociaż zastanawiam się, czy napewno (sic!) jej intencjąbyło to, żeby mi sprawić przyjemność czy raczej 
to, żebym się zaczęla zastanawiać czy wszystko ze mną w porządku.

Ich wundere mich und fühle mich verarscht. Höflich bedanke ich mich.

Danke für das Kompliment... Gefühle dabei: sagt sie das jetzt, weil sie sich freut, dass ich Scheiße aussehe..., ansonsten hat sie keinen Grund, mir Kompliment zu machen.

Akt podziękowania jest zatem ważną strategia grzecznościowa Niemców i Polaków i może być traktowany jako model respon$s e^{4}$, jako odpowiedź zgodna z panującymi zasadami grzeczności w danym kraju, „idealna”, poprawna odpowiedź, jakiej się oczekuje. Ciekawe jest to, że akt podziękowania występuje nie tylko w reakcjach akceptujących komplementy czy też nastawionych na uniknięcie chwalenia się, lecz również w przypadku odrzucenia go, przy czym trzeba zaznaczyć, że taki przykład zostal znaleziony tylko w ankietach niemieckich: Danke für die Blumen. Taka wypowiedź w języku niemieckim to ironiczna forma podziękowania za krytykę. Tym samym stanowi ona atak na twarz osoby komplementującej, gdyż daje się jej odczuć, że komplement jako komplement odebrany nie zostal, wręcz przeciwnie.

Na podstawie tabeli można jeszcze stwierdzić, że komentarze wykazuja podobną frekwencję występowania w obu kulturach, czego nie da się powiedzieć o zgodzie czy komplemencie zwrotnym, które dominują u Niemców. Niemcy lubią rewanżować się za uzyskany komplement tym samym, by sprawić radość jego nadawcy. Pytania (?) pojawiające się w reakcjach, jak np. Serio?, Poważnie?, Podrywasz mnie? sa zadawane przez Polaków o 1,8\% częściej. Czterech ankietowanych $z$ Niemiec (3,3\% wszystkich werbalnych odpowiedzi) przyznaje, że zmienia temat po otrzymaniu komplementu. Takie zachowanie może sugerować, że odbiorca nie do końca wie, jak się w danej sytuacji zachować, bądź jest ona dla niego krępująca i dlatego próbuje odwrócić uwagę nadawcy poprzez skierowanie rozmowy na inny temat. U polskich studentów podobnego zachowania nie

4 Pojęcie to wprowadza Pomerantz w 1978 roku. 
stwierdzono. Zdecydowanie najrzadziej występującym elementem reakcji zarówno u Polaków, jak i Niemców jest transfer czyli „przesunięcie" komplementu na inną osobę lub np. kolor, któremu nadawca zawdzięcza otrzymany komplement, przykładowo:

Danke, aber das gute Aussehen ist meinem Friseur zu verdanken, da kann ich nichts dafür.

Das liegt an der Farbe. Das hellt das Gemüt auf.

„Dziękuję, to pomysl fryzjera.” Jest mi miło, że moja fryzura podoba się innym.

\section{Wyniki ogólne}

Klasyfikacja wszystkich 242 werbalnych reakcji na komplementy, uzyskanych na podstawie trzech sytuacji, pozwolily sformulować następujace wyniki obrazujace ogólne preferencje ankietowanych w doborze strategii w odbiorze komplementu:

\begin{tabular}{l|c|c|c|c}
\multirow{2}{*}{$\begin{array}{c}\text { Typ } \\
\text { odpowiedzi }\end{array}$} & \multicolumn{2}{c|}{$\begin{array}{c}\text { niemieccy } \\
\text { respondenci }\end{array}$} & \multicolumn{2}{c}{$\begin{array}{c}\text { polscy } \\
\text { respondenci }\end{array}$} \\
\cline { 2 - 5 } & liczba & $\%$ & liczba & $\%$ \\
\hline I Akceptacja & 85 & 69,1 & 84 & 70,6 \\
\hline II Odrzucenie & 7 & 5,7 & 8 & 6,7 \\
\hline $\begin{array}{l}\text { III Uniknięcie } \\
\text { chwalenia się }\end{array}$ & 31 & 25,2 & 27 & 22,7 \\
\hline razem & 123 & 100 & 119 & 100
\end{tabular}

Tabela 3 Ogólne preferencje Polaków i Niemców w reakcjach na komplementy 
Analiza wykazala stosunkowo dużą zgodność w preferowanych strategiach zachowań studentów niemieckich i polskich po otrzymaniu komplementu. Jak widać, obydwie grupy ankietowanych w większości akceptują komplementy. Warto jednak podkreślić, że respondenci polscy decydowali się na strategię akceptacji o 1,5\% częściej. Można więc uznać, że obydwie kultury są zorientowane na zaspokojenie potrzeb twarzy pozytywnej osoby komplementujacej, nawet jeśli może to być związane z potencjalną utratą własnej twarzy. Tym samym w świetle teorii Brown i Levinson można stwierdzić, że polscy i niemieccy studenci są ukierunkowani na grzeczność pozytywną (positive politeness). Akceptujac komplement, respondenci przyjmuja pozytywne wartościowanie, zgadzają się z opinią nadawcy komunikatu i szanujajego zdanie. Taka reakcja zdaje się być powszechnie oczekiwaną odpowiedzią na komplement w obydwu krajach, o czym świadczy jej wysoka frekwencja, tym bardziej, że jak wynika z analizy, mimo tego, że czasem odbiorcy komplementu nie są do końca przekonani co do szczerości intencji osoby komplementującej, doszukują się drugiego dna i manipulacji, nie dają tego odczuć nadawcy, dbają o jego pozytywną twarz, wybierając grzeczną odpowiedź w postaci podziękowania.

$\mathrm{Na}$ drugim miejscu znalazły się strategie, które mają na celu częściową akceptację komplementu przy równoczesnym pomniejszeniu obiektu komplementu bądź podwyższeniu wartości osoby komplementujacej lub przeniesieniu pozytywnego wartościowania na inną osobę czy obiekt. 25,2\% Niemców próbuje obejść dylemat związany z reakcją na komplement wlaśnie w ten sposób, w przypadku Polaków takie strategie można było zaobserwować u 22,7\% respondentów.

Jak wynika z danych procentowych odrzucenie komplementu występuje najrzadziej w porównaniu z akceptacją czy unikaniem chwalenia się, co dowodzi, że respondenci niechętnie sięgaja po takie rozwiązanie. 6,7\% polskich studentów odrzuca komplement, czyli o 1\% częściej niż Niemcy.

Powszechnie panuje przekonanie, że Polacy raczej odrzucaja komplementy: A.: Ale tadna sukienka B.: A taki tam stary ciuch. Z 10 lat w szafie wisi. Tymczasem, jak wynika z analizy, komple- 
menty tak naprawdę są w większości akceptowane, a ewentualne umniejszenie obiektu komplementowanego pojawia się w strategii unikania chwalenia się:

Naprawdę? Ależ ja mam ten sweter od dawna. Myślałem, że to nic szczególnego. Ale jest mi bardzo milo.

Dzięki, mam nadzieję, że będzie lepiej niż z tą nudną starą „szopą na glowie”. I chyba się udało (-) Miło, że powiedzialaś, co myślisz.

\section{Zakończenie}

W artykule przedstawiono fragmenty pracy magisterskiej pt. ,Zum respondierenden Komplimentverhalten der deutschen und polnischen Studenten", napisanej pod kierunkiem Beaty Mikolajczyk. Przytoczono niektóre wyniki analizy zachowań polskich i niemieckich studentów dotyczących odbioru komplementu „Dzisiaj wyglądasz pięknie!" oraz ogólne preferencje w wyborze strategii reagowania na komplementy. Na podstawie uzyskanych danych można stwierdzić, że podobieństwa zarysowaly się przede wszystkim w ogólnym zachowaniu polskich i niemieckich studentów, a więc:

- dla niej dbaniem o twarz pozytywną nadawcy komplementu, wiążące się z potencjalną utratą twarzy odbiorcy

- akceptacja jako najczęściej występujaca strategia, za nią unikanie chwalenia się, a najrzadziej odrzucenie komplementu

- akt podziękowania jako akt mowy najczęściej pojawiający się w reakcjach respondentów

Różnic należalo szukać przede wszystkim we frekwencji występowania poszczególnych elementów odpowiedzi (aktu podziękowania, zgody z komplementem, komplementów zwrotnych, transferu, pytań czy zmiany tematu):

- znacznie częstsze stosowanie przez Niemców komplementu zwrotnego jako strategii unikania chwalenia się, zgodzenia się z komplementem jako strategii akceptacji 
- rzadsza o $1,8 \%$ frekwencja występowania pytań (?) i o $0.9 \%$ komentarzy wśród Niemców

- zmiana tematu ujęta w reakcji tylko w niemieckiej części korpusu (u czterech ankietowanych)

oraz w przykladach dotyczacych konkretnych sytuacji (sytuacja nr 3 ankiety), na podstawie których można $\mathrm{m}$. in. stwierdzić:

- większą bezpośredniość reakcji wśród polskich studentów, polączoną z ewentualna utratą twarzy osoby komplementującej w odróżnieniu od strategicznych grzecznych odpowiedzi studentek polskich i niemieckich.

Mimo iż komplementy i reakcje na nie sq uniwersaliami kulturowymi, to jednak charakteryzują się mniejszą lub większą różnorodnością (por. Farghal/Al-Khatib 2001: 1486). Kultura polska i niemiecka cechuje się z jednej strony podobnym obrazem grzeczności, co można stwierdzić na podstawie dość zbliżonych wyników procentowych preferowanych reakcji na komplement, ale oprócz tego w każdej $z$ nich widoczne są również odmienne zachowania osób komplementowanych, swoiste i oryginalne, dzięki czemu każda z tych kultur staje się niepowtarzalna i jedyna w swoim rodzaju.

\section{Bibliografia}

Chen, R. 1993: Responding to compliments. A contrastive study of politeness strategies between American English and Chinese speakers. In: Journal of Pragmatics (20). 49-73.

Farghal, M./Al-Khatib, 2001: Jordanian college students' responses to compliments: a pilot study. In: Journal of Pragmatics 33. 1485-1502.

Mikolajczyk, B. 2008: Wyrażenia znieważające jako leksykalne środki realizacji aktów zagrażajacych twarzy na przykładzie języka niemieckiego i polskiego. In: Kontakty językowe i kulturowe w Europie. Studia Germanica Gedanensia 17. Gdańsk: Wydawnictwo Uniwersytetu Gdańskiego. 186-197.

Nicolaysen, S. 2007: Kompliment als Höflichkeitsstrategie. Ein Vergleich am Beispiel des Schwedischen und des amerikanischen Englischen. Saarbrücken: VDM Verlag Dr. Müller. 
Schulze, R. 1985: Höflichkeit im Englischen. Zur linguistischen Beschreibungund Analyse von Alltagsgesprächen. Tübingen: Gunter Narr Verlag.

Zborowski, P. 2005: Dankbarkeit vs. Höflichkeit und sprachliche Routine. Der Dankakt im Schwedischen verglichen mit Polnisch und Deutsch. Poznań: Wydawnictwo Naukowe UAM. 


\section{Komplimenterwiderungen der deutschen und polnischen Studierenden}

\section{Liebe Studierende,}

zunächst einmal gebe ich Euch einige Informationen zu den Zielen meiner Untersuchung:

- Die Ergebnisse dieser Umfrage sollen Auskunft darüber geben, wie die verbalen Reaktionen auf Komplimente in Deutschland und Polen aussehen und was für Unterschiede und Ähnlichkeiten sie aufweisen.

- Ich möchte wissen, wie Ihr auf Komplimente reagiert. Es geht um Eure persönliche Meinung und alltägliche Erfahrung. Deshalb gibt es keine richtigen und falschen Antworten.

- Jede Antwort auf die vorliegenden Fragen ist von großer Bedeutung. Deshalb möchte ich Euch um ein gewissenhaftes Ausfüllen des Fragebogens bitten. Lest bitte die unten angeführten Situationen und schreibt Eure spontanen Erwiderungen auf.

- Ich sichere Euch völlige Anonymität zu, was Auswertung der Ergebnisse betrifft.

- Wenn Ihr etwas über die Ergebnisse dieser Umfrage erfahren möchtet, nehmt bitte im Sommersemester 2009 Kontakt mit mir per E-Mail (vfranko@wp.pl) auf.

\section{Vielen Dank für Eure Mitarbeit!}

Violetta Frankowska 


\section{Wskazówki do ankiety:}

Proszę o:

- jak najdokładniejsze opisywanie reakcji werbalnych w pytaniach otwartych (kilka zdań)

- w pytaniach zamkniętych zaznaczenie krzyżykiem odpowiedzi dotyczacej Was

- nieopuszczenie żadnego pytania

- spontaniczne odpowiedzi

- czytelne pismo

\section{Reakcje na komplement}

Sytuacja nr 1:

Jutro wieczorem wychodzisz z przyjaciólmi. Dlatego sprawiasz sobie nową fryzurę. W dniu spotkania wszyscy są pod wrażeniem Twojego nowego wizerunku. Twoja dobra koleżanka stwierdza: „W tej nowej fryzurze wyglądasz świetnie!”

Sytuacja nr 2

Masz nową fryzurę. Pewna osoba, z którą nie stoisz na przyjacielskiej stopie, zwraca się do Ciebie: „W tej nowej fryzurze wyglądasz świetnie!" 
Sytuacja nr 3

Wstajesz dzisiaj wcześnie rano, jesteś w bardzo dobrym humorze i zakładasz nie tak jak zawsze ciemnobrazowy sweter i szare spodnie, lecz Twoje nowe jasne ubranie. Wszyscy od razu zauważają tę nagla zmianę. Kolega/koleżanka z roku mówi do Ciebie: „Dzisiaj wyglądasz pięknie!"

\section{Dane osobowe}

kobieta mężczyzna

........ lat

Kraj:

Niemcy Polska

Kierunek studiów:

Serdecznie dziękuję! 